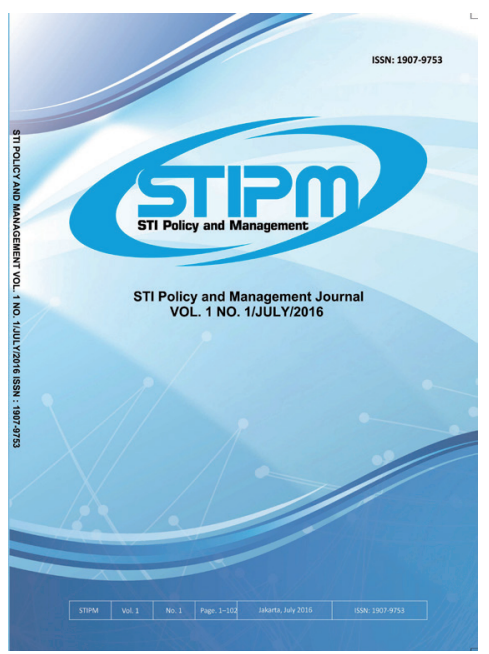

Journal of STI Policy and Management

Publication details, including instructions for authors and subscription information: http://www.stipmjournal.org/

\title{
Innovation System Reform in Indonesia and Vietnam: A New Role for Universities?
}

\section{Erik Baark}

Division of Social Science and Division of Environment, Hong Kong

University of S\&T, Clearwater Bay, Kowloon, Hong Kong

Version of record first published: 15 July 2016

To cite this article: Baark, E. (2016). Innovation System Reform in Indonesia and Vietnam: A New Role for Universities?. Journal of STI Policy and Management, 1(1), 1-15

To link to this article: http://dx.doi.org/10.14203/stipm.v1i1

ISSN 1907-9753 (Print); ISSN 2502-5996 (online)

Accreditation Number: 622/AU3/P2MI-LIPI/03/2015

Full terms and conditions of use: https://creativecommons.org/licenses/by-nc-sa/4.0/

You are free to:

- Share $\quad$ : copy and redistribute the material in any medium or format

- Adapt : remix, transform, and build upon the material

- The licensor cannot revoke these freedoms as long as you follow the license terms.

Under the following terms:

Attribution - You must give appropriate credit, provide a link to the license, and indicate if changes were made. You may do so in any reasonable manner, but not in any way that suggests the licensor endorses you or your use.

NonCommercial - You may not use the material for commercial purposes.

ShareAlike - If you remix, transform, or build upon the material, you must distribute your contributions under the same license as the original.

No additional restrictions - You may not apply legal terms or technological measures that legally restrict others from doing anything the license permits.

Notices:

- You do not have to comply with the license for elements of the material in the public domain or where your use is permitted by an applicable exception or limitation.

- No warranties are given. The license may not give you all of the permissions necessary for your intended use. For example, other rights such as publicity, privacy, or moral rights may limit how you use the material.

- If you copy the dataset merely to extract the uncopyrightable data elements would not need permission to do so. However, if you republish the full dataset or using the copyrightable data layers require a permission from PAPPIPTEK-LIPI. 


\section{JOURNAL OF STI POLICY AND MANAGEMENT}

Volume 1 No. 1 July 2016

\section{LIST OF CONTENTS}

Innovation System Reform in Indonesia and Vietnam: A new Role for Universities?

Erik Baark.

Technology and Standardization Strategies related to the Diffusion of Smart Houses: The Case of ECHONET in Japan

Kumiko Miyazaki, Kentaro Nishida

Intellectual Property Creation of Japanese Companies in China and Thailand

Masayuki Kondo.

Technological Capability Upgrading and Entrepreneurship: Case Study of Selected Indonesian Fish Processing Companies

Erman Aminullah, Trina Fizzanty, Galuh S. Indraprahasta, and Indri J. Asmara

Influential Factors of Evidence-Based Energy Policy-making: Government Regulation on Targeting Renewable Energy in Indonesia

Wati Hermawati, Prakoso Bhairawa Putera, Dudi Hidayat, and Ishelina Rosaira P.

Finding the Most Efficient Technology Transfer Route Using Dijkstra Algorithm to Foster Innovation: The Case of Essential Oil Developments in the Research Center for Chemistry at the Indonesian Institute of Sciences

Arief A. R. Setiawan, Anny Sulaswatty, and Agus Haryono 


\section{in STI POLICY AND MANAGEMENT

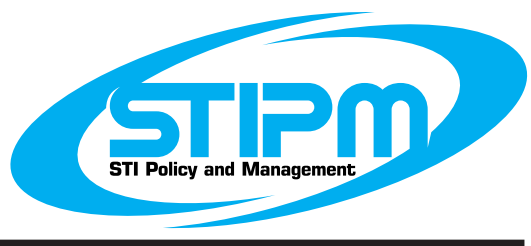

\section{Innovation System Reform in Indonesia and Vietnam: A new Role for Universities?}

\section{Erik Baark}

Division of Social Science and Division of Environment, Hong Kong University of S\&T, Clearwater Bay, Kowloon, Hong Kong

\begin{tabular}{|c|c|}
\hline ARTICLE INFO & ABSTRACT \\
\hline $\begin{array}{l}\text { Article History: } \\
\text { Received : } 28 \text { January } 2016 \\
\text { Revised : } 15 \text { April } 2016 \\
\text { Accepted : 26 June } 2016 \\
\text { Available online : } 15 \text { July } 2016\end{array}$ & $\begin{array}{l}\text { This paper introduces the importance of the role of universities in } \\
\text { emerging economies such as Indonesia and Vietnam, underscoring the } \\
\text { need for universities to contribute more extensively to the dynamic } \\
\text { development of innovation systems. The theoretical approach is a } \\
\text { functional analysis of innovation systems, identifying essential issues }\end{array}$ \\
\hline $\begin{array}{l}\text { Keywords: } \\
\text { Innovation systems } \\
\text { University-industry linkages } \\
\text { Indonesia } \\
\text { Vietnam }\end{array}$ & $\begin{array}{l}\text { that call for recognition among policymakers and in society generally. } \\
\text { Innovation systems in Indonesia and Vietnam share some weaknesses, } \\
\text { particularly in comparison with innovation systems in more advanced } \\
\text { countries. There is limited ability to mobilize the resources required } \\
\text { for innovation, as the investment in research and development as } \\
\text { percentage of GDP is relatively low and dominated by public funding } \\
\text { with little contribution from private sources. Financial regulation for } \\
\text { universities seriously hampers the development of university-industry } \\
\text { linkages. It is essential that universities gain more autonomy in order to } \\
\text { move beyond their current role in training of skilled human resources } \\
\text { to providers of innovation. }\end{array}$ \\
\hline
\end{tabular}

\section{INTRODUCTION}

Indonesia and Vietnam have experienced economic growth in recent years that has led these two countries to be considered second-tier emerging markets (Deloitte, 2012). In fact, these countries have weathered the aftermath of the global financial crisis in 2008 even better than several of the BRICS countries have. This is partly related to the predominance of exports of raw materials and agricultural products in each country. Both countries also exhibit an economic structure

\footnotetext{
* Corresponding Author. Tel: +852-23587831

E-mail: sobaark@ust.hk
}

dependent on medium or low technological levels, and a very small high-technology sector. Foreign direct investment has been growing, but not at a rate that is comparable to other emerging markets like China, and most investments has entered in sectors that are based on raw materials extraction, labor-intensive industries and services such as tourism.

Although these emerging markets have achieved economic growth, the weak technological infrastructure and low productivity in most sectors of the economy is a major barrier to future development. Therefore, there is a definite need 
to upgrade the innovation system in both countries in order to facilitate access to more advanced technology and to adapt technological solutions to the domestic context. The Government of Vietnam has adopted an ambitious strategy for the development and application of science and technology (S\&T) until 2020, aiming to boost the value of high-tech products to $45 \%$ of total industrial production value by 2020 and to increase the amount of international scientific publications by $15-20 \%$ per year during the decade ("PM approves...", 2012).

The Indonesian Government has also proposed to reform and upgrade the national innovation system. The OECD has recently issued a report on innovation in Southeast Asia that includes detailed profiles of these new policies in Vietnam and Indonesia, together with an analysis of their context in terms of the existing strengths and weaknesses of innovation systems in the two countries (OECD, 2013). The OECD report shows that in spite of structural and institutional differences, both Indonesia and Vietnam share challenges in terms of providing adequate funding for R\&D and improving linkages between various innovation actors in the economy.

The aim of this paper is to assess the potential for Indonesia and Vietnam as emerging economies in Asia to use innovation as a key driver of development, following the trends that have set East Asian countries such as Japan, South Korea and China on a path to advanced, industrialized and innovative economies. At the same time, the historical conditions of the two countries are mutually different to the extent that one would expect significant variation in the innovation systems and role of universities. Although both countries emerged from colonial political and economic regimes in the post-World War II years, Indonesia formally achieved its independence from Dutch rule in 1949, while Vietnam struggled to unify the country for decades until 1976. Indonesia's economy followed a traditional development path and achieved substantial economic growth for three decades before being hit by the Asian financial crisis in 1997; economic growth has picked up again during the last decade, but much of the structure of a mixed economy and the balance between public and private innovation activities has remained the same (Thee, 2012). Vietnam, in contrast, emerged from decades of war and a legacy of socialist planned economic development when the leadership decided to introduce market reforms in 1986, and has since witnessed one of the highest rates of economic growth in Asia (Steinfeld and Thai, 2013). The transition in Vietnam has brought about a mix of state-owned and private firms, a greater commercial orientation of public research institutes and a rapid expansion of the higher education sector, including both public and private universities. These diverging experiences provide an interesting background for examining the similarities and differences that exist in the institutional framework and functional characteristics of Indonesian and Vietnamese systems of innovation.

\section{THEORETICAL FRAMEWORK}

There are many good reasons for policy makers to provide support for universities, especially in recent decades, when the impact of institutions supporting the generation and dissemination of knowledge in economic development has become evident. This has been recognized by both international organizations and governments that are concerned with the functions of innovation systems and their capacity to support the economy. Consequently, I will here briefly introduce some of the most relevant and useful theoretical perspectives on the emergence of university-industry linkages and analysis of innovation systems for developing effective innovation policies.

\section{A. Theories of Industry-University Partnerships: Understanding Institutional Embeddedness in Innovation Systems}

There has been growing interest from policy makers and academics in the commercial impact of university intellectual property. The academic research output reflects a substantial increase in the level of involvement by universities in technology commercialization activities, and universities are now expected to play a significant 
role as incubators of entrepreneurial resources in a vigorous and thriving innovation system. A study by Allen and Wong (2004) observed that technology transfer activities in Pacific Rim universities occur at a much lower level than in American universities, but also pointed out that such activities were growing at faster rates.

The literature on university technology transfer primarily focuses on two modes of output. On one hand, many studies focus on patents/ technology licensing (Thursby \& Kemp, 2002; Shane, 2002) and on the other hand, others analyze transfer in the form of university spin-offs (Shane \& Stuart, 2002). Research collaboration among teams of scientists and/or researchers from the corporate sector is a topic that has attracted increased attention in recent decades, and frequently this type of relationship forms the basis of university-industry linkages; for instance, Mowery and Sampat (2005) provided a concise analysis of both the US and international experience in a comparative perspective. A recent review of the scientific literature in the field found that trust between partners is essential for the success of the collaboration and that firm learning is one of the most significant outputs (Bozeman \& Boardman, 2014).

Efforts to develop a better understanding of the role of universities and research institutions has increasingly been conceptualized within the Triple Helix model of innovation-driven economic growth (Etzkowitz, 2008), in which these institutions work closely in complex, interactive relationships with government agencies and private enterprise (Leydesdorff and Meyer, 2006). The Triple Helix concept also provides a comprehensive framework for studying the new role of universities in practical terms. This perspective makes reference to the tensions that emerge as core responsibilities of universities in training human capital for the future development of the knowledge-based society conflicts with various profit motives of industry (Etzkowitz and Leydesdorff, 2000). Similar concerns emerge with the mission-oriented drivers of a Mode 2 approach to research (Nowotny, Scott and Gibbons, 2001).

Universities should encourage an attitude of learning to learn, that is, to develop dynamic and flexible learning patterns that allow students to further develop their skills and new knowledge. In this way, universities develop their second key function of research, and the role of doctoral studies in the portfolio of teaching expands. Ultimately, research becomes vital for the third mission of universities, namely, to contribute to the application of new knowledge, entrepreneurship and support for innovation in society (Laredo, 2007). This transition has happened in many countries, with the effect that both advanced research universities and traditional colleges have increasingly come to underscore their functions as gatekeepers of innovation in the economy.The argument here is that, in addition to the two basic missions of teaching and research, entrepreneurial universities engage in the third mission of contributing to society by diffusing knowledge to the local community, thereby generating research and consultancy income and assisting regional development.

Together, the literature that has emerged in this field of research during the last two decades thus provide a set of theoretical and methodological approaches for understanding the role of universities in advanced economies and the influence of policies designed to enhance the commercialization of technology through university-industry linkages. International experience suggests that the effectiveness of intermediaries in the innovation system depend to a considerable degree on the organizational set-up and responsiveness of intermediary organizations vis-à-vis industry partners (Siegel, Waldman \& Link, 2003). It is necessary to understand technology transfer from universities to the commercial sector within its broader context of innovation systems and their institutional features (see Carlsson \& Fridh, 2002). The success of a technology transfer process depends not only on the interface between the university and the business community, but also on the receptivity of the surrounding community and the institutions, organization and incentives within the universities themselves. Many of the institutional features of universities are linked to the policies for S\&T and the innovation environment generally - for instance, the legal and administrative effectiveness of intellectual property protection. 
Despite recent changes, there is great scope for organizations to play a yet more proactive role in the technology transfer process, specifically by engaging more closely with industry associations, industry leaders, and also SMEs (the most challenging category of industry players). However, the role of such intermediaries can only be effectively understood within the broader framework of academia-industry-government relationships. Yet even such a framework needs to be situated within an understanding of the innovation system in question. In particular, there are specific elements of the innovation system that have an impact upon potential linkages, including the scope and effectiveness of the intellectual property regime and the availability of financial support (which includes the banking system and availability of venture capital funding, as well as conduciveness of the local stock markets for promoting start-ups). Such elements have often been emphasized in recent research on university-industry linkages in Asia (see, e.g. Sharif \& Baark, 2008, 2011a, and 2011b). These institutional characteristics are, to a large degree, determined by the structure of the innovation system and the development of new institutions created by institutional reform.

\section{B. Analysis of Innovation Systems and Innovation Policy Assessment}

The concept of a national innovation system (NIS) has influenced the approach to science and innovation policy in most countries. However, in some developing countries the effectiveness of this approach has been greatly limited by a focus on the R\&D system rather than the innovation system. While R\&D may be a useful proxy for innovation in developed countries, it is not so in developing economies, where $R \& D$ is not a major driver of development. In 'catching-up' economies, the key process is technological capability development, learning from the global stock of knowledge and learning how to apply this knowledge. Capability development can be seen as a process of learning, and hence an innovation system is more perhaps more usefully termed a learning system. However, it is important to recognize that all actors in the 'system' have to learn how to create value. In the case of firms, the market will select which firms create more value for customers and stakeholders, and those that are unable to change will fail. Nevertheless, what of public sector organizations? How do they learn to create value? What is the selection and improvement mechanism that drives continuous improvement? Moreover, what of policymakers and those who administer public programs - how do they learn?

Policies that explicitly promote and support capability upgrading in firms have been of great importance in many countries. However, such policies (and innovation policies in general) have little impact if a range of other policies is not consistent with these objectives. Thus, a reform of the innovation system that aims to encourage long-term investments in capability development requires close coordination of policies in areas such as trade, investment, education, and human resources that create an institutional framework for indigenous learning. The application of the NIS concept to innovation policy thus implies that the complete set of institutional factors influencing the creation and application of knowledge are surveyed, in order to remove inefficiencies and obstacles to linkages in the economy and to dynamic learning processes for the various actors in the system.

A recent approach to developing an analysis of a national innovation system has become known as the functional assessment of NIS. There are actually several different analytical perspectives that underscore the importance of understanding the various functions performed in an innovation system. The first conceptual framework for a functional approach was launched by Liu and White (2001), who identified five essential functions of an innovation system, as illustrated by China's experience. This was subsequently elaborated by Edquist $(2005,2008)$ into a perspective outlining ten different activities that were structured into four thematic categories: (i) the provision of knowledge inputs to the innovation process; (ii) demand side activities; (iii) the provision of constituents of systems of innovation; and (iv) support services for innovating firms. However, the most well-developed 
conceptual approaches were those proposed by a group of Swedish researchers led by Staffan Jacobsson that focused on analysis of three structural components and seven dynamic functions of innovation systems (Bergek, Jacobsson, Carlsson, Lindmark \& Rickne, 2008). The focus of several studies has been on specific technological sectors (not the entire national innovation system), such as the development of renewable energy. Another elaborate approach has been conceptualized by a group of Dutch researchers who have analyzed innovation in the environmental sector (Hekkert, Suurs, Negro, Kuhlmann \& Smits, 2007), and it has been applied to environmental industry innovations in the Netherlands.

The specific seven functions of innovation systems that will constitute the conceptual and methodological focus of this paper are:

1. Resource mobilization: The extent to which an innovation system is able to mobilize essential resources for innovation, such as funding, human resources, infrastructure, instrumentation, etc.

2. Knowledge development: How key actors such as universities, research institutes and firms - become involved in developing new knowledge.

3. Market formation: The extent to which the innovation system promotes new markets for innovative products; for example, through government procurement.

4. Influence on direction of research: How innovation policy directs actors' research efforts towards areas of priority.

5. Entrepreneurial experimentation: How innovation systems support new firms, SMEs and ideas.

6. Legitimacy: Whether or how cultural values and institutional frameworks in the innovation system encourage innovation.

7. Development of external economies: How domestic and international networks support innovation.

The essential point is that analysis of an innovation system can focus on the way that the system supports a variety of functions - both in the supply of knowledge and innovative products, and in the demand for innovation. In such analytical approaches, it is important to understand the extent to which actors will be able to perform their functions and jointly contribute to the innovation processes of the system. Moreover, a key issue is the extent to which the institutional framework is providing adequate inducements or incentives for innovative functions - or whether existing institutions act as blocking mechanisms for such functions. Policies should therefore be designed to enhance incentives and remove blocking mechanisms for each of the essential functions. In other words, innovation policy assessment requires a wider scope of analysis than R\&D inputs and outputs. This type of assessment encourages a deep understanding of the ways in which a range of policies (including economic policies, tax policies, trade and investment policies, IPR policies, educational policies, etc.) provide the right incentives for innovation. For the purpose of this paper, we shall focus on whether - and in what ways - universities in Indonesia and Vietnam are able to develop and implement their functions in the innovation system.

A qualitative research methodology has been applied in the collection and analysis of data for this paper. A range of documentary sources on economic and technological development in the two countries was examined to illustrate the functions of the two innovation systems. Additionally, data was collected during selected case study interviews with representatives from universities and other research institutions in Indonesia and Vietnam to investigate the institutional blocking mechanisms or incentives for collaboration with industry or entrepreneurial spin-off activities. Interviewers provided consent for the taping of interviews and the use of anonymous data for research purposes at the beginning of each interview.

\section{INNOVATION SYSTEM REFORM IN INDONESIA AND VIETNAM}

This section provides a background to our discussion of the role of universities in the innovation systems of Indonesia and Vietnam, and the extent to which recent reforms have sought to mobilize universities in these two countries in the task of 
supporting innovation and capability development.

As mentioned earlier in this paper, Indonesia and Vietnam have shared almost two decades of substantial economic growth. Much of that growth has been generated by labor-intensive and/or resource-intensive sectors of the economy, while nascent high-technology sectors have played a minor role. In particular, the reliance on foreign sources of technology among major firms has continued, and foreign investment has dominated vital industries such as electronics and transportation equipment (motorbikes and automobiles). The innovation systems in Indonesia and Vietnam therefore both remain relatively weak, even if there are significant differences in the structure and actors.

One very significant factor in the weakness of both systems has been the low level of financial resources for $R \& D$. In particular, the $R \& D$ investment as a percentage of GDP is less than a tenth of a $\%$ in Indonesia, while it is a quarter of a $\%$ in Vietnam. In particular, investment in and implementation of $\mathrm{R} \& \mathrm{D}$ is dominated by government and public organizations - for example, the Indonesian Institute of Sciences (LIPI) and the Agency for Assessment and Application of Technology (BPPT) in Indonesia, and the Vietnam Academy of Science and Technology (VAST) in Vietnam - while the private sector allocates very few resources to innovation.

Therefore, innovation policy reforms in Vietnam have attempted to improve the function of mobilizing more resources for R\&D among private sector actors, which contribute less than $20 \%$ of investment in R\&D. A new science and technology development strategy for the period of 2010-2020 was approved by Prime Minister Nguyễn Tấn Dũng in 2012. The strategy proposes to boost the value of high-tech products to $45 \%$ of total industrial production value by 2020 and to increase the amount of international scientific publications by $15-20 \%$ per year during the decade ("PM approves ...", 2012).

In Indonesia, a strategy formulated relatively recently called the Master Plan for Acceleration and Expansion of Indonesian Economic Growth (MP3EI) 2011-2025 envisages the active pro- motion of economic development in six major regional corridors. In addition, the former Indonesian president, Susilo Bambang Yudhoyono, has been very eager to raise the private investment in $\mathrm{R} \& \mathrm{D}$, and his administration pushed forward an initiative known as 1-747. This policy aims to spur the country into devoting $1 \%$ of GDP for research, implementing seven steps of innovation systems improvement, adopting four modes of economic growth acceleration, and achieving the seven objectives of Indonesian Vision 2025. This includes a new initiative to establish science and technology parks in major Indonesian cities, thus strengthening both the national innovation system and regional innovation systems in the country (Soenarso, Nugraha \& Listyaningrum, 2013).

However, the government struggles to raise the financial resources needed. The largest corporations in Indonesia have traditionally been reluctant to enter into long-term investments in R\&D and technological development, while very small enterprises (which constitute more than $90 \%$ of Indonesian firms) usually have few resources - whether financial resources or human resources - to invest in innovation. There are good opportunities to promote private $R \& D$ investment through tax incentives, and in fact the Government of Indonesia has already promulgated seven different regulations to provide incentives for $R \& D$ tax deductions by private firms; however, as a recent analysis pointed out, the implementation of these regulations has not been successful (Soenarso and Sadewo, 2014, p. 29). So far the 'resource mobilization' function of the Indonesian innovation system is lagging seriously behind comparable countries. For the 'market formation' function, procurement policies designed to encourage the development of innovative products in the economy have hardly been utilized in Indonesia and Vietnam. Procurement policies have been very successfully pursued by the US Department of Defense in order to promote microelectronics and computer networks in the United States, and in several European countries to further the development of mobile communications standard GSM and renewable energy. However, they require substantial input from the government, including financial support for purchases and innovation support to industrial 
firms, as well as subtle institutional and regulatory approaches that provide strong incentives to domestic actors while at the same time conforming to WTO guidelines.

The 'knowledge development' function and the 'influence on the direction of research' function are probably those that have been pursued most explicitly in Vietnam and Indonesia. The traditional supply-oriented S\&T policies in these two countries have emphasized science planning (i.e. direction of research) and support for research in public organizations (i.e., knowledge development) that would allegedly be "transferred to industry/society". In actuality, this kind of transfer seldom took place. Some of the reasons appear to be that the absorptive capacity of the firms that were supposed to receive the knowledge developed was too weak, and that the firms did not have strong incentives to rely on domestic sources of new knowledge. This was especially so as they would have to undertake extensive development to implement the knowledge - which would usually not be the case with foreign, 'proven' technology. Policies frequently ignored the fact that the 'knowledge development' function requires close linkages and collaboration between research organizations (public research institutes or universities) and industry.

Finally, the function of "promoting innovative entrepreneurial experimentation' is a fundamental precondition for a dynamic innovation system. In both Indonesia and Vietnam, this function of the innovation system has not received sufficient attention. In fact, it is possible to argue that the attention that innovative entrepreneurs have received in Indonesia and Vietnam has often been negative: regulations and popular culture has all too often been based on a suspicion that entrepreneurs are "corrupt" or "profiteering". For example, a survey found that more than 8 in 10 Indonesians say that corruption is widespread throughout the nation's government and businesses (Gallup, 2011). Establishing new firms face substantial bureaucratic hurdles and takes much longer than in countries like Singapore and Malaysia. Raising money for entrepreneurial initiatives is difficult, both because public funding is limited and private funding (for example, bank loans) is frequently extremely difficult to obtain. This issue is also connected to the function of 'legitimation', namely, the extent to which society is genuinely supportive of innovative activities, persons and firms. There are many rhetorical statements purporting to recognize and celebrate innovation, but few actual policies and promising markets that could provide genuine incentives for innovative products.

\section{UNIVERSITIES AND INDUSTRY LINKAGES IN INDONESIA AND VIETNAM}

In this section, I shall illustrate some of the promising experiences of universities that contribute to the fundamental functions of mobilizing knowledge for innovation in Indonesia and Vietnam. It is noteworthy that both Indonesia and Vietnam have registered a relatively high percentage of GDP for expenditure on education. Indonesia's share of public expenditure on education as percentage of GDP is $2.8 \%$, while Vietnam currently has public expenditure of $5.34 \%$ of GDP on education - even outperforming Singapore (3.28\%) in this respect (World Bank, 2012, p. 116). Universities are generally a critical component of higher education in Indonesia and Vietnam, and this sector has experienced periods of promotion mixed with other periods of neglect in both countries. For example, Indonesia developed its higher education infrastructure slowly during the 1950s and 1960s, but accelerated training of researchers in the $1980 \mathrm{~s}$, primarily relying on overseas doctoral education in Europe and the US. Vietnam also utilized overseas opportunities for advanced education, relying primarily on training in the Soviet Union and East European countries. Throughout the twentieth century, universities in many developing countries, including Indonesia and Vietnam, have been regarded as organizations for advanced professional or vocational training, and very few universities have developed advanced research or postgraduate training. Indonesian public expenditure on tertiary education is reported as $1.2 \%$ of GDP, and Vietnam's public expenditure on tertiary education is about the same, namely $1.18 \%$ (World Bank, 2012, p. 116). 
Therefore, the transition to a new role of universities in the innovation system requires two important processes. First, universities need to complement their fundamental educational function with a stronger emphasis on research. Second, they need to engage more strongly with society and industry in order to fulfill their 'third mission', i.e. to contribute actively to knowledge development and innovative capabilities.

The first element of the transition principally involves creating a better internal, institutional environment: mobilizing the financial support and career incentives in universities to engage professors, postgraduate students and even undergraduate students in research-intensive learning. This transformation of the internal environment for research and innovation of course depends on external regulation and resources. The core issue for both Indonesia and Vietnam appears to be whether - and how - a higher level of autonomy can be granted to universities, thus removing the blocking mechanisms that hamper promotion of research and the pursuit of careers relying on innovation. A further development of institutions actively supporting research orientation and advanced scholarship in universities can also assist universities in becoming gatekeepers for international exchange of knowledge - thus fulfilling the development of external economies function in the innovation system. This means that universities and their faculty members need to develop and enhance the international academic linkages, and use these linkages to facilitate knowledge development in domestic industries.

The second element of the transition is contingent on a change in the wider context and institutional environment for universities. There is a need to reduce the external institutional constraints for the universities so that they can better serve the society and the economy. This requires social and political will to reform other essential functions of the innovation system namely, to create a stronger social demand for the knowledge development and innovative services that could be provided by universities.

In particular, the two functions of 'market formation' and 'entrepreneurial experimenta- tion' in society should interact closely with the possibilities of universities to develop their 'third mission'. The governments in Indonesia and Vietnam should be able to influence the formation of markets for innovative products, partly by co-funding projects with industries that need innovative inputs, and partly through direct intervention, which can be achieved with public procurement. For example, the government may steer its procurement of pharmaceutical drugs towards new medicines that are needed in society, while simultaneously it could provide strong incentives for industries and universities to collaborate on relevant pharmaceutical R\&D. In other cases, universities require support for spin-off entrepreneurial ventures, either through companies set up by professors or graduates, or through the attraction of entrepreneurial firms that can commercialize the technology developed via university research.

\section{A. University-industry Linkages in Indonesia}

The following paragraphs discuss the general issues of developing cooperation between researchers and business in Indonesia, together with preliminary results from interviews with university representatives. A recent major study of the conditions for interaction between university, industry and government partners in Indonesia provides rare insight into the factors that promote or constrain such interaction. The study emphasized that in addition to the poor level of financial resources for R\&D in Indonesian universities, there are several prominent issues related to the institutional framework of the educational system that hold back partnerships between universities, industry and government:

One of the most fundamental issues is the lack of understanding and mutual trust between the three sectors. Too many universities develop their strategies without recourse to industrial stakeholders, and many academics look down on industries, considering them 'greedy' and 'lacking idealism'. On the other hand, industrialists consider universities to be ivory towers, bureaucratic, and too focused on consensus building to meet industry needs... A second issue is that there is a serious flaw in the institutional framework 
allowing public universities to engage in partnership with industry. Public universities' lack of financial autonomy makes it difficult for them to run projects efficiently. And having no legal status gives them no credibility in negotiating contracts involving intellectual property rights. Without autonomy, institutional development occurs without the institutional mechanisms or structures for strategic actions (Education Sector Analytical and Capacity Development Partnership, 2013, p. xi).

The study investigated a range of universities providing training for undergraduates, and although most universities had weak capabilities in both providing quality education and utilizing research, there were a few practically oriented institutions that had developed extensive contacts with industry (for example, Universitas Surabaya and Institut Pertanian Bogor) and promoted entrepreneurial activities. The universities with a stronger research orientation (such as Universitas Indonesia, Universitas Gajah Mada, Institut Teknologi Bandung, and Institut Teknologi Sepuluh Nopember) have strong ambitions to develop internationally competitive fundamental research, but most of these universities also pursue research that is locally relevant, and have sought to develop better cooperation with partners in industry and society.

For example, interviews at Institut Teknologi Bandung (ITB) indicated that many professors at ITB were undertaking consultancy work that was associated with alumni and performed via seven key research centers (ITB Interview, 18 August 2014). Many of the projects are in areas of specialized strength, such as construction design, energy, oil and gas. An important intermediate organization established in 2004 is PT. LAPI ITB, which is an enterprise set up to generate funds for research activities at ITB through consultancy service projects and training courses. LAPI has grown substantially in recent years, having a turnover of 200-300 projects per year, and has transferred a dividend to ITB that has increased from 2.4 billion rupiah in 2011 to 6.9 billion rupiah in 2013 (PT. LAPI Interview, 18 August 2014). Some of the projects are undertaken for the public sector, but more than $90 \%$ of the clients are from the private sector. Other firms have been established by ITB in order to promote commercialization of research; however, LAPI has the broadest scope and is the most profitable consulting company, and in fact has established subsidiaries for consultancy in fields such as water, IT, etc. The managers of LAPI - retired professors from ITB - believe that there are additional market opportunities both domestically in Indonesia and overseas, but they have been constrained in pursuing the expansion due to a lack of human resources in the company and limitations in the time that professors can devote to the research and consulting activities. LAPI has a considerable advantage over other companies set up by ITB in the engineering and construction services market due to its classification as a Class A company, which means it can undertake large-scale engineering projects.

Of course, some professors and students have established their own private companies, without any direct association or official links with ITB. The university has recently also been successful in creating spin-off companies, for instance in commercializing energy technology developed at the university. But it was still difficult for ITB to directly support the creation of entrepreneurial firms spinning off technologies by professors or students, and a study has shown that most patents granted to staff have not yet been commercialized (Ameka \& Dhewanto, 2013). Although there are some ITB staff and alumni have connections to the local Bandung Techno Park, the university is not directly engaged in this initiative, which is run by another local university, Telkom Institute of Technology (Soenarso, Nugraha \& Listyaningrum, 2013).

The University of Indonesia (UI) has also been actively promoting linkages with industry and the commercialization of technology from the university's research. There is a Directorate for Partnership and Business Incubation, which is responsible for promoting IPR licensing to the industry and the creation of new entrepreneurial firms for marketing of services and products (UI Interview, 22 August 2014). In spite of holding quarterly presentation of research results from UI, the response from government and in particular industry has been disappointing - few industries have shown interest in licensing UI technology. 
Out of 82 patent applications, 15 have been granted patent rights, and less than 10 have been utilized.

On the other hand, entrepreneurship by professors and students has been quite active, as well as by consultancy companies; for instance, PT. Daya Makara, which was established in 2004 and PT. Makaramas, which was established in 2009. The latter company has commercialized an IT product for ATM systems, which earns 700 million rupiah every month in royalty. Students from UI have been creating new firms after graduation, and at least 130 were listed in a recent report. The university is also in the process of developing a science park together with the Korean government. Nevertheless, these universities, as well as the Institut Teknologi Sepuluh Nopember (ITS) and public research organizations such as LIPI and BPPT, all found it difficult to expand their role in society. The principal barriers were related the status of the organizations and the financial regulations - in other words, the level of autonomy for public universities and research organizations. The current regulations constrain the level of financial autonomy for universities and their staff in particular. The abovementioned report gives a concise summary:

Under the existing public finance regime, all revenues in public universities are state revenues. The implication is that all disbursement and procurement activities have to comply with the bureaucratic and cumbersome mechanisms of public finance regime. Moreover, goods procured become state assets, while, in most cases, industry demands full ownership of the product prototype (including the goods procured) (Education Sector Analytical and Capacity Development Partnership, 2013, p. 62).

The result of these difficulties is that faculties are in fact discouraged from cooperating with industry through official arrangements with the university. Instead, unofficial arrangements and consultancy appear to flourish, but of course the university has not been fully able to collect data on such activities (ITS Interview, 26 August 2014). In a similar way, regulations for the current status of ITS as a public organization do not facilitate the establishment of new firms by the university. It is hoped that changes in the status could improve this situation, and there are already three companies in the making, commercializing new products and services in the information technology (IT) sector (a data center), mining (new smelter), and the automotive industries. The administration at ITS was thus encouraged that there were a demand for services and technologies from the university, but felt constrained by the regulatory framework in its efforts to officially support cooperation with industry and entrepreneurship of ITS staff.

Interviews with universities in Indonesia thus confirmed that there are both opportunities and a willingness among university administrations and staff in Indonesia to engage more actively in cooperation and partnership for innovation with industry and society. Even if the R\&D funding and capabilities in Indonesia are relatively weak, there are possibilities for expanding the function of universities in the innovation system. Examples such as ITB and ITS show that willingness and enthusiasm among professors and students to engage in entrepreneurial projects were widespread, but regulations and uncertainties in the market reduced the actual possibilities for staff and students to move forward under the current context. Unfortunately, the status of universities do not provide the kind of autonomy required for them to play this role, largely because the administrative and financial regulations reduces flexibility and introduces delays and conditions for the transfer of resources that industry will usually find difficult to accept. Therefore, innovative entrepreneurship tended to be conducted in unofficial ways or by students after graduation, thereby losing some of the crucial information feedback for the university's own knowledge repository.

\section{B. University-industry Linkages in Vietnam}

In Vietnam, an agenda for reforms of the higher education sector was issued in 2005 , which has sought to raise the quality of teaching in higher education through degree requirements for teachers, higher levels of research, and increased income from S\&T activities (Harman \& Ngoc, 2010). According to assessments carried out in 
the early 2000s, the majority of universities had a low research productivity, reporting problems such as lack of adequate time for research, lack of appropriate working conditions, and the absence of financial incentives to engage in research:

Academics in Vietnam understandably have a strong orientation to teaching which takes up most of their time. Amongst many academics there is a relatively low interest in research for which funding is limited especially for junior staff. Universities do not see technology transfer activities as being crucial for their existence. In many instances, technology facilities and innovation rates in universities are behind that of leading firms. Within universities, research institutes with research-only staff undertake the bulk of research activity.

Many problems related to staffing are officially recognised by government authorities but there remains a need for realistic strategies and funding allocations to make a difference. Staff-student ratios are recognized to be too high. There are notable variations in the quality of academic staff across institutions, while there is no effective framework for decisions about career advancement, particularly appointment at the professorial level. (Harman \& Ngoc, 2010, p. 98)

The challenges for developing technology transfer are partly related to the weakness of technological capabilities and R\&D in Vietnamese industry and agriculture - a problem that is accompanied by a perspective from industry that, among other things, shows a fundamental desire to work with universities, but difficulties in negotiation, learning and sharing of information (Fatseas, 2010, p. 108). Several high-technology parks have been established in the vicinity of universities in Vietnam in the hope that this would foster increased university-industry linkages; however, the successful expansion of such linkages in the parks has been questionable.

The policy framework for encouraging university-industry cooperation is still largely shaped by the Law on Technology Transfer adopted in 2001. This law contains a new emphasis on intellectual property as a chief vehicle for the transfer of knowledge and technology. However, given that few universities in Vietnam are oriented towards the development of patented technology, and the institutional regime for intellectual prop- erty rights in Vietnam is still relatively weak, this aspect has not yet gained the importance as an incentive for university staff that was envisaged in the law.

The growth of demand for higher education in Vietnam has provided incentives for development of postgraduate training and, gradually, the expansion of research-based education and training, for example through $\mathrm{PhD}$ programs. Fourteen key universities have also received particular attention and are strongly encouraged to develop science and technology research through special funding and creation of research facilities and promotion of international linkages.

As a key university, the Vietnam National University (VNU) is a major institution with branches in Hanoi and in HCM City, encompassing some of the oldest and most well-developed universities in Vietnam. The VNU Science branch in Hanoi has a long tradition of conducting research and has developed new competence in advanced technology such as nanotechnology. Having secured extensive funding in Vietnam and from abroad, it is developing technologies for textiles and biological components (VNU Interview, 19 April 2015). However, the challenge is that few industries in Vietnam have the technological capabilities to exploit this technology, making it necessary to provide extensive prototype testing, development and assistance for transfer. It is also a challenge that there is a lack of highly trained technicians that can be employed by the university to handle experiments in the laboratory. Similarly, PhD students in Vietnam tend not to be careful enough in operating and maintaining the equipment, which occasionally causes major breakdowns.

Another Vietnamese public institution of higher education that has had a relatively long history of collaboration with industry and the community is the Cần Thơ University, established in 1966, selected as one of the fourteen key universities and located in the Mekong Delta. In this university, approximately one-third of the budget comes from the Ministry of Education, one-third from tuition fees, and another one-third from research funds (Cần Thơ University Interview, 9 January 2015). The Cần Thơ University has 
had extensive collaboration with Germany and is strong in international cooperation. Because of the location of the university in the Mekong Delta, much of the partnership with the community has focused on agriculture, aquaculture and biotechnology. The university has established an incubation center to encourage staff and students to create new firms selling services and innovations.

However, universities based on private finance have gained a level of autonomy that the prestigious public key universities frequently lack. For example, the Tôn Đức Thắng (TDT) University established in 1997 in HCM City is classified as an independent public university - providing it with the status of independent financial accounting, but with no financial subsidies from the government. TDT University has developed more than 14 research centers to help professor and students link up with industry. Part of the effort is to create good conditions for student internships with industry, and part of it has been giving assistance to research contracts funded by industry (Interview at TDT, 5 January 2015). Although most staff is lecturers expected to devote $70-80 \%$ of their time to teaching and $20 \%$ to research, the university has also appointed a number of research lecturers who are expected to spend $70-80 \%$ of their time on research and $20 \%$ on teaching.

The interviews conducted in Vietnam showed that the reform of the higher education sector is moving forward at a moderate speed. The problem of financial autonomy still exists, and the weak demand for innovative technologies from industry and other elements of society is holding back the ability of universities to function effectively as conduits for innovation. Like Indonesia, the university sector in Vietnam requires much stronger and targeted support to be able to supplement its basic role as provider of skilled human resources with a new role as a nucleus of innovation promotion in the society.

\section{CONCLUSION}

This paper briefly introduces the importance of transforming the role of universities in contemporary emerging economies and enhancing the ability of universities to contribute more extensively to the dynamic development of innovation systems. I use the recently developed conceptual framework of a functional analysis of innovation systems to analyze the status of innovation systems in Indonesia and Vietnam, and identify some essential functional issues that calls for additional recognition among policy makers and in society generally. A better understanding of these functional aspects of the innovation systems may lead to innovation policy reform, and such reforms may be able to mobilize the contributions of universities to a greater extent. Moreover, the paper demonstrates that the functional analysis framework can be used to examine the particular role that universities play in innovation systems - that is, it can help us understand where the universities can provide specific contributions, and help us identify the incentives or blocking mechanisms that influence their performance.

An overview of the innovation systems in Indonesia and Vietnam shows that they share some characteristics, particularly in comparison with innovation systems in more advanced countries. There is limited ability to mobilize the resources required for innovation, as the investment in R\&D as percentage of GDP is relatively low and dominated by public funding with little contribution from private sources. In Indonesia, private businesses appear reluctant to commit investment to innovation that does not provide an assured return within a short time span, and large firms often remain dependent on transfer of technology from overseas sources. Human resources for innovation are growing, partly due to the expansion of the higher education system, but the overall supply of highly trained and experienced researchers is still insufficient for many industries. In Vietnam, the economic reforms have unleashed a growing private sector, but most firms are still reluctant to commit substantial investment to innovation. In a similar way, knowledge development efforts are also concentrated in public organizations and operating in a supply-dominated policy environment, with little engagement in market formation and demand-oriented activities. 
Given some of these weaknesses of the Indonesian and Vietnamese innovation systems, is is clear that the universities represent a vital resource for enhancing innovation in the two countries. Nevertheless, the role of universities seems to have been locked in traditional concepts where they are considered primarily organizations designed to communicate knowledge, with little emphasis on the essential research and advanced postgraduate training functions that characterize many universities elsewhere. Interviews in Indonesia illustrated that both staff and students at key universities were keen to link up with industry or set up new entrepreneurial ventures based on the knowledge generated within the university. But regulations limiting the autonomy of the universities acted as effective barriers to regular exploitation of such opportunities. In Vietnam, $R \& D$ activities in universities have been actively promoted for a number of years, and although the legal and regulative framework for innovation and university-industry linkages also presented barriers to expansion, Vietnam appeared poised to undertake a transformation of the universities' role towards provision of knowledge development function. It was also possible to identify strong support for entrepreneurial experimentation critically important for the commercialization of innovations, particularly at some of the more advanced universities in the South of Vietnam.

\section{ACKNOWLEDGEMENTS}

In doing the research for this paper, I have relied heavily on the assistance and inspiration from colleagues in Indonesia and Vietnam. In particular, I wish to thank Mr. Dudi Hidayat and Dr. Don Scott-Kemmis for their support in Indonesia, while in Vietnam I have been grateful for the assistance provided by Dr. Bach Tan Sinh and Dr. Dao Thanh Truong. Research funding was provided by a grant from the HKUST Institute for Emerging Market Studies.

\section{REFERENCES}

Allen, K. \& Wong, P. K., (2004). Technology Spin-offs from Pacific Rim Universities: Entrepreneurial Context and Economic Impact. Singapore: APRU Secretariat National University of Singapore.
Ameka, I. \& Dhewanto, W. (2013). Technology Push vs. Market Pull in Technology University Innovation: Commercialization case study: ITB. Information Management and Business Review, 5(7), 337-341.

Bergek, A., Jacobsson, S., Carlsson, B., Lindmark, S., \& Rickne, A. (2008). Analyzing the functional dynamics of technological innovation systems: A scheme of analysis. Research Policy, 37(3), 407-429.

Bozeman, B., \& Boardman, C. (2014). Research collaboration and team science: A state-of-the-art review and agenda. Springer. http://dx.doi. org/10.1007/978-3-319-06468-0

Carlsson, B., \& Fridh, A. C. (2002). Technology transfer in United States universities - A survey and statistical analysis. Journal of Evolutionary Economics, 12(1-2), 199-232.

Center for S\&T Development Studies (Pappiptek). (2015). Science and technology in Indonesia - In brief 2014. Jakarta: Indonesian Institute of Sciences (LIPI).

Deloitte. (2012). Securing the next level for growth: Second-tier emerging markets. Retrieved June 2016 from http://www2.deloitte.com/ content/dam/Deloitte/nl/Documents/consumerbusiness/deloitte-nl-securing-the-next-levelfor-growth-second-tier-emerging-markets.pdf

Edquist, C. (2005). Systems of innovation: Perspectives and challenges. In J. Fagerberg, D. Mowery, and R. Nelson (Eds.), Oxford handbook of innovation (pp. 181-208). Oxford: Oxford University Press.

Edquist, C., \& Hommen, L. (Eds.). (2008). Small country innovation systems: Globalization, change and policy in Asia and Europe. Cheltenham, UK: Edward Elgar.

Education Sector Analytical and Capacity Development Partnership. (2013) Developing strategies for university, industry and government partnership in Indonesia. Jakarta: Education Sector Analytical and Capacity Development Partnership (ACDP). Retrieved June 2015 from http:// www.acdp-indonesia.org/en/publications/ acdp-025-developing-strategies-for-universityindustry-and-government-partnership/

Etzkowitz, H. (2008). The Triple Helix: Universityindustry-government innovation in action. London: Routledge.

Etzkowitz, H., \& Leydesdorff, L. (2000). The dynamics of innovation: from National Systems and "Mode 2" to a Triple Helix of university-industry-government relations. Research Policy, 29(2), 109-123. 
Fatseas, M. (2010). Research-industry cooperation supporting development in Vietnam: The challenge of translating policy into practice. In G. Harman, M. Hayden \& P. T. Nghi, (Eds.), Reforming higher education in Vietnam (pp. 87-102). Springer. http://dx.doi. org/10.1007/978-90-481-3694-0_7

Gallup (2011). Corruption Continues to Plague Indonesia. Retrieved 15 June 2016 from http:// www.gallup.com/poll/157073/corruptioncontinues-plague-indonesia.aspx

Harman, G. \& Ngoc, L. T. B. (2010). The research role of Vietnam's universities. In G. Harman, M. Hayden \& P. T. Nghi, (Eds.), Reforming higher education in Vietnam (pp. 103-115). Springer.

Hekkert, M. P., Suurs, R. A. A., Negro, S. O., Kuhlmann, S., \& Smits, R. E. H. M. (2007). Functions of innovation systems: A new approach for analysing technological change. Technological Forecasting and Social Change, 74(4), 413-432.

Laredo, P. (2007). Revisiting the third mission of universities: Toward a renewed categorization of university activities? Higher Education Policy, 20, 441-456.

Leydesdorff, L., \& Meyer, M. (2006). Triple Helix indicators of knowledge-based innovation systems: Introduction to the special issue. Research Policy, 35, 1441-1449.

Liu, X., \& White, S. (2001). Comparing innovation systems: a framework and application to China's transitional context" Research Policy 30(6), pp. 1091-1114

Mowery, D. C., \& Sampat, B. N. (2005). Universities in national innovation systems. In J. Fagerberg, D. Mowery \& R Nelson (Eds.), The Oxford handbook of innovation. Oxford University Press.

Nowotny, H., Scott, P., \& Gibbons, M. (2001). Rethinking science: Knowledge and the public in an age of uncertainty. London: Polity Press.

Organisation for Economic Co-operation and Development (OECD). (2013). Innovation in Southeast Asia. Paris: OECD Publishing.

OECD \& World Bank. (2014). Science, technology and innovation in Viet Nam, Paris: OECD Publishing. http://dx.doi.org/10.1787/19934211

PM approves 2010-2020 Science and Technology Development Strategy. (2012) Vietnam News. Retrieved 15 June 2016 from http:// vietnamnews.vn/politics-laws/223444/pmapproves-2010-2020-science-and-technologydevelopment-strategy.html
Siegel, D. L., Waldman, D., \& Link, A. (2003). Assessing the impact of organizational practices on the relative productivity of university technology transfer offices: An exploratory study. Research Policy 32, 27-48.

Shane, S. (2002). Selling university technology: Patterns from MIT. Management Science, 48(1), 122-137.

Sharif, N. \& Baark, E. (2008). Mobilizing technology transfer from university to industry: The experience of Hong Kong universities. Journal of Technology Management in China, 3(1), 47-65.

Sharif, N., \& Baark, E. (2011a). The transformation of research technology organizations (RTOs) in Asia and Europe. Science, Technology \& Society, 16(1), 1-10.

Sharif, N., \& Baark, E. (2011b). The Hong Kong University of Science and Technology: A case study in entrepreneurial-university-led knowledge-based economic development. In Academic entrepreneurship in Asia: The role and impact of universities in national innovation. Cheltenham, UK: Edward Elgar.

Shetty, P., Akil, H., Fizzanty, T., \& Simamora, G. (2014). Indonesia: The atlas of Islamic world science and innovation country case study San Francisco: Creative Commons. Retrieved from https://royalsociety.org/ /media/policy/ projects/atlas-islamic-world/2014-09-03-Atlas Indonesia.PDF

Soenarso, W.S, Nugraha, D., \& Listyaningrum, E. (2013). Development of Science and Technology Park (STP) in Indonesia to support innovation-based regional economy: Concept and early-stage development. World Technopolis Review, 2(1), 32-42 http://dx.doi. org/10.7165/wtr2013.2.1.32

Soenarso, W. S., \& Sadewo, H. (2014). A strategy to increase Indonesian private sector R\&D investment. Asia-Pacific Tech Monitor, 31(2), 25-31.

Steinfeld, J. M., \& Thai, K. V. (2013). Political economy of Vietnam: Market reform, growth, and the state. Baltimore, MD: University of Maryland School of Law.

Thee, K. W. (2012). Indonesia's economy since independence. Singapore: Institute of Southeast Asian Studies.

Thursby, J. G., \& Kemp, S. (2002). Growth and productive efficiency of university intellectual property licensing. Research Policy, 31(1), $109-124$ 
World Bank. (2012). Putting higher education to work: Skills and research for growth in East Asia [World Bank East Asia and Pacific regional report]. Washington, DC: The World Bank.

http://dx.doi.org/10.1596/978-0-8213-8490-9
World Economic Forum. (2014). The global competitiveness report 2014-2015. Geneva: World Economic Forum. Retrieved from http://www3. weforum.org/docs/WEF GlobalCompetitivenessReport_2014-15.pdf 